\title{
Phagocytosis of Group B Streptococcus by Neutrophils from Newborn Infants
}

\author{
MARY CATHERINE HARRIS, ${ }^{(35)}$ JOHN STROOBANT, CAROLYN S. CODY, STEVEN D. DOUGLAS, \\ AND RICHARD A. POLIN \\ Divisions of Neonatology and Allergy-Immunology of The Children's Hospital of Philadelphia and The Joseph Stokes \\ Jr. Research Institute and the Department of Pediatrics of the University of Pennsylvania School of Medicine, \\ Philadelphia, Pennsylvania, USA
}

\begin{abstract}
Summary
The purpose of this study was to investigate the effect of severe "stress" on neonatal neutrophil (PMN) phagocytosis, and to compare the ability of neonatal and adult PMNs to ingest $\left[{ }^{3} \mathbf{H}\right]-$ labeled type Ic group B streptococcus (GBS). Three patient populations were studied: healthy and "stressed" newborn infants and healthy adults. Severe "stress" was defined as an acute, noninfectious respiratory illness, sepsis or severe birth asphyxia; 94\% of these infants required assisted ventilation. Radiolabeled GBS was opsonized with $5 \%$ adult serum, and incubated with PMN monolayers adherent to glass coverslips. Bacterial uptake was determined at $0,40,60$, and $80 \mathrm{~min}$ and expressed as counts per $\min / 10^{6}$ PMNs. Neutrophis from healthy and "stressed" newborn infants demonstrated a significant increase in bacterial uptake with time. Adult controls also showed a significant increase in phagocytosis through $60 \mathrm{~min}$, but not during the 60-80 min time period. PMNs from "stressed" and healthy infants demonstrated enhanced bacterial uptake when compared to adults at 40,60 , and $80 \mathrm{~min}$. There were no significant differences in bacterial ingestion between "stressed" and healthy infants. Radiolabeled GBS uptake did not correlate with birth weight, study age, Apgar scores, or peripheral leukocyte count for the "stressed" newborn population. Neutrophils from healthy and "stressed" newborn infants thus demonstrate increased phagocytosis of GBS when compared to healthy adults.
\end{abstract}

\section{Abbreviations}

CPM, counts per minute

GBS, group B streptococcus

PBS, phosphate buffered saline

PMN, polymorphonuclear leukocytes

Despite recent advances in neonatal intensive care and the use of broad spectrum antimicrobial agents, GBS sepsis remains a fulminant, rapidly fatal disease during the newborn period. Currently, GBS is the most frequent bacterial isolate recovered from infected infants less than 3 months of age $(3,10)$. The increased susceptibility of the newborn infant to bacterial infection is multifactorial, but is principally due to developmental deficiencies of the neonatal immune system (19). Although studies of white blood cell function have produced conflicting data, abnormalities of adherence $(8,14,18)$, chemotaxis $(2,15,20,22,28,31)$, phagocytosis $(9,19)$, oxidative metabolism $(30,32)$, and intracellular killing $(23,26,33)$ have been demonstrated for both PMN and mononuclear leukocytes.

The results of previous investigations of neonatal neutrophil phagocytosis have varied because of differences in study population, concentration of opsonin, nature of the phagocytic particle ingested, and phagocyte to particle ratio $(6,7,17,24)$. Stress has been suggested as an additional factor which may further compromise neonatal immune function $(9,21)$.
The purpose of this study is to investigate the effect of severe stress on phagocytosis by neutrophils from newborn infants, and to compare the ability of PMNs from newborn infants and adults to ingest radiolabeled type Ic group B streptococcus.

\section{MATERIALS AND METHODS}

Patient population. The study population consisted of 33 "stressed" and 15 healthy newborn infants admitted to the Infant Intensive Care Units at The Children's Hospital of Philadelphia and the Hospital of the University of Pennsylvania, and 22 healthy adult volunteers (Table 1).

"Stress" was defined as an acute, noninfectious respiratory illness, sepsis, or severe birth asphyxia (Apgar score of 5 or less at 1 and $5 \mathrm{~min}$ ). The "stressed" newborn population included 25 infants with respiratory distress syndrome, four infants with aspiration syndromes, two infants with sepsis, and two infants with asphyxia. Twenty-one of 33 "stressed" infants required intermittent mandatory ventilation, 10 required endotracheal continuous positive airway pressure, and two infants received hood oxygen alone (Table 2). Twenty-nine of 33 infants were studied within 4 days of birth.

Healthy newborn infants from 31-40 wk gestation were enrolled from the Obstetrical Service at the Hospital of the University of Pennsylvania. Ten $\mathrm{ml}$ of blood was obtained from doubly clamped cord segments at delivery. Infants with respiratory illnesses, birth asphyxia, hypoglycemia, or shock were excluded from the study. Written permission was obtained from parents for all blood samples in accordance with the policies of the Human Investigation Committee at The Children's Hospital of Philadelphia and the Hospital of the University of Pennsylvania. Control blood was obtained from healthy adults routinely used as donors for our laboratory.

Neutrophils from "stressed" or healthy newborn infants were always tested in combination with an adult sample on the same day; however, in only 11 instances were all three populations studied simultaneously.

Preparation of bacteria. The reference strain of GBS type Ic (A909-14) was supplied by the late Dr. Rebecca Lancefield. A single loop of GBS was incubated in $10 \mathrm{ml}$ Todd Hewitt medium containing $0.25 \mathrm{ml} \mathrm{L}-4,5-\left[{ }^{3} \mathrm{H}\right]$-leucine aqueous solution containing $2 \%$ ethanol $(25 \mu \mathrm{Ci} / \mathrm{ml}$, specific activity: $52 \mathrm{Curies} / \mathrm{mmole})$ at $37^{\circ} \mathrm{C}$ overnight. The following day the GBS were quantitated by inoculating bacteria in serial dilutions on blood agar plates. Organisms were heat-killed at $60^{\circ} \mathrm{C}$ for $1 \mathrm{~h}$, washed three times in PBS, resuspended to $1 \times 10^{8}$ organisms $/ \mathrm{ml}$, and either used immediately or stored overnight at $4^{\circ} \mathrm{C}$.

Opsonizing procedure. Serum for opsonization was obtained from a single adult donor with known high antibody titer to type Ic GBS, and diluted to 5\% with PBS (25). Immediately before use, group B streptococci $\left(5 \times 10^{7}-1 \times 10^{8} \mathrm{CFU} / \mathrm{ml}\right)$ were opsonized by mixing $2.5 \mathrm{ml}$ of the bacterial suspension with $0.75 \mathrm{ml}$ of $5 \%$ adult serum in a sterile capped tube $(12$ by $75 \mathrm{~mm}$; Falcon Plastics, 
Table 1. Study population

\begin{tabular}{|c|c|c|c|c|c|c|}
\hline & $\begin{array}{c}\text { Birthweight } \\
\text { (g) } \\
(\mathrm{M} \pm \text { S.D. })\end{array}$ & $\begin{array}{c}\text { Gestational } \\
\text { age (wk) } \\
(\mathrm{M} \pm \text { S.D. })\end{array}$ & $\begin{array}{l}\text { Apgar score } \\
(M \pm \text { S.D. })\end{array}$ & $\begin{array}{l}\text { Mode of } \\
\text { delivery }\end{array}$ & $\begin{array}{c}\text { Study } \\
\text { age (days) }\end{array}$ & $\begin{array}{c}\text { Leukocyte } \\
\text { count } \\
\times 10^{3} / \mathrm{mm}^{3} \\
(\mathrm{M} \pm \text { S.D. })\end{array}$ \\
\hline & Range (2820-4150) & Range (31-40) & $8.9 \pm 0.7(5 \mathrm{~min})$ & $50.0 \%$ SVD & & \\
\hline "Stressed" newborn infants & $2019.6 \pm 990.4$ & $33.5 \pm 4.9$ & $4.8 \pm 2.6(1 \mathrm{~min})$ & $57.6 \% \mathrm{SVD}$ & $2.8 \pm 3.0$ & $11.9 \pm 6.6$ \\
\hline
\end{tabular}

' ECS, elective caesarian section; SVD, spontaneous vaginal delivery; and CS, Caesarian section.

${ }^{2}$ Samples obtained from cord blood at delivery.

${ }^{3}$ Data not obtained.

Table 2. Respiratory parameters, "stressed" newborn infants"

\begin{tabular}{lccc}
\hline & $\begin{array}{c}\text { Infants on IMV } \\
(\mathrm{M} \pm \mathrm{S} . \mathrm{D} .)\end{array}$ & $\begin{array}{c}\text { Infants on CPAP } \\
(\mathrm{M} \pm \text { S.D. })\end{array}$ & $\begin{array}{c}\text { Infants on } \\
\text { hood oxygen } \\
(\mathrm{M} \pm \text { S.D. })\end{array}$ \\
\hline & $(n=21)$ & $(n=10)$ & $(n=2)$ \\
$\mathrm{FiO}_{2}$ & $0.46 \pm 0.25$ & $0.32 \pm 0.11$ & $0.34 \pm 0.05$ \\
$\mathrm{IP}(\mathrm{mm} \mathrm{Hg})$ & $17.2 \pm 3.9$ & & \\
$\mathrm{CPAP}(\mathrm{mm} \mathrm{Hg})$ & $4.3 \pm 1.2$ & $3.9 \pm 0.9$ & \\
IMV & $36.2 \pm 21.6$ & & \\
\hline
\end{tabular}

${ }^{1} \mathrm{FiO}_{2}, \%$ inspired oxygen; IP, inspiratory pressure; CPAP, continuous positive airway pressure; and IMV, intermittent mandatory ventilation (breaths per min).

Division of Bioquest, Oxnard, CA). This mixture was rotated at $37^{\circ} \mathrm{C}$ for $30 \mathrm{~min}$. After incubation, tubes were centrifuged at 800 $\times g$ for $10 \mathrm{~min}$ at room temperature, the bacteria washed twice in $\mathrm{PBS}$, and resuspended to the original volume $(2.5 \mathrm{ml})$ in RPMI 1640 without serum. Supernatant from SP2/0-Ag-14, a murine myeloma cell line was used as a negative control.

Preparation of leukocytes. Equal volumes of heparinized blood from newborn or adult donors and 3\% dextran in normal saline were sedimented at $37^{\circ} \mathrm{C}$ for $1 \mathrm{~h}$. The leukocyte-rich plasma was removed, and the cells washed twice at $4^{\circ} \mathrm{C}$ with $\mathrm{PBS}$ at $400 \times \mathrm{g}$. After counting in $2 \%$ acetic acid, the cells were resuspended in PBS to a final concentration of $1.5 \times 10^{6}$ polymorphonuclear leukocytes/ml.

Radiolabeled bacterial uptake. Phagocytic uptake was determined by a modification of the methods of Mandell (16) and Allred et al. (1). Monolayers of neutrophils isolated by dextran sedimentation were prepared by incubating $0.2 \mathrm{ml}$ of the leukocyte suspension on glass coverslips $\left(15-\mathrm{mm}\right.$ diameter) at $37^{\circ} \mathrm{C}$ for 30 min. Non-adherent cells were washed off with PBS, and $0.2 \mathrm{ml}$ $\left(2 \times 10^{7}\right.$ organisms) of the opsonized, labeled bacterial suspension was added to each coverslip, giving a bacteria to phagocyte ratio of approximately 100:1. At intervals of $0,40,60$, and $80 \mathrm{~min}$, coverslips were vigorously washed with $\mathrm{PBS}$, Placed in poly $\mathrm{Q}$ scintillation vials (Beckman) with $10 \mathrm{ml}$ of aqueous counting scintillant (ACS II, Amersham), and counted for $5 \mathrm{~min}$ in a Beckman LS-7500 scintillation counter.

Coverslips were tested in quadruplicate at each time point, and representative samples washed and stained with Wright's solution (Fig. 1). Using this procedure, the number of extracellular bacteria was minimal. The number of adherent neutrophils was determined using a $10 \mathrm{~mm}$ square grid under $\times 40$ magnification. PMN adherence for the three patient populations was as follows: "stressed" infants $1.6 \pm 0.6 \times 10^{5} /$ coverslip (cs), healthy infants $1.8 \pm 0.4 \times 10^{5} / \mathrm{cs}$ and adults $2.3 \pm 0.7 \times 10^{5} / \mathrm{cs}$ (mean \pm S.D.). There was a significant difference in PMN adherence between "stressed" newborn infants and adults $(P<0.001)$, although there were no significant differences in PMN adherence between "stressed" and healthy infants, or between healthy infants and adults. These differences in adherence are currently under investigation in our laboratory. Scintillation counts, CPM, reflecting radiolabeled bacterial uptake by adherent neutrophils, were expressed per $10^{6}$ phagocytes and plotted against time.

Statistics. Data between patient groups were analyzed using

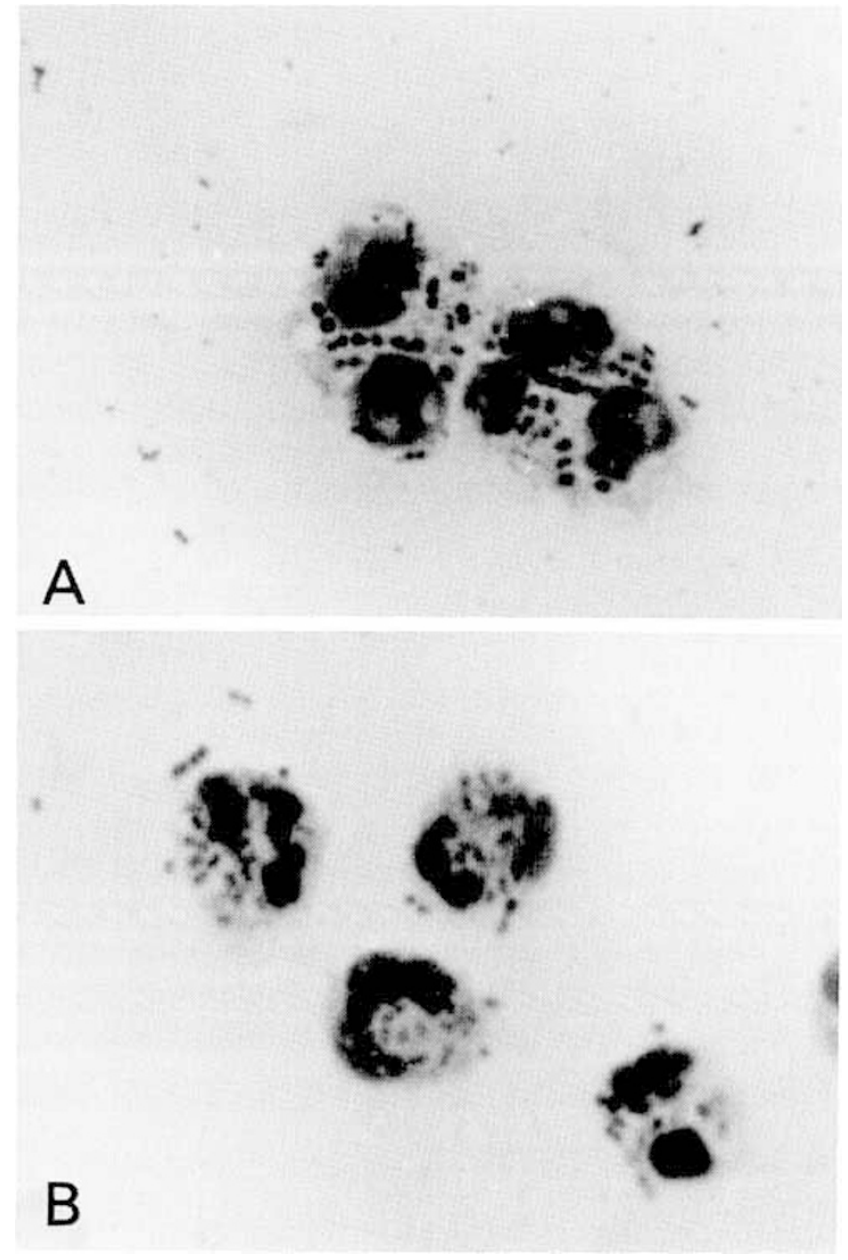

Fig. 1. Ingestion of type Ic GBS by neutrophils from newborn infants (Fig. la) and adults (Fig. 1b).

two-way repeated measures analysis of variance. Multple time comparisons within groups were analyzed using a one-way analysis of variance. Correlations between variables were performed using least-squares linear regression analysis.

\section{RESULTS}

Kinetics of radiolabeled bacterial uptake. Neutrophils from healthy and "stressed" newborn infants demonstrated a significant increase in uptake of radiolabeled bacteria with time ("stressed": 0-40 min, $P<0.001$, 40-60 $\mathrm{min}, P<0.001$, and 60-80 $\mathrm{min}, P<$ 0.01 ; healthy: $0-40 \mathrm{~min}, P<0.001,40-60 \mathrm{~min}, P<0.025$, and 60 80 min, $P<0.05$ ) (Table 3). Adult controls in contrast, showed a significant increase in phagocytosis at $0-40 \mathrm{~min}(P<0.001)$, and 40-60 min $(P<0.01)$, but not during the $60-80 \mathrm{~min}$ time period $(P=\mathrm{NS})$.

Radiolabeled bacterial uptake: "stressed" and healthy neonates vs adults. Polymorphonuclear leukocytes from "stressed" newborn 
Table 3. Radiolabelled bacterial uptake with time $\left(\mathrm{cpm} / 10^{6}\right.$ neutrophils)

\begin{tabular}{|c|c|c|c|c|c|}
\hline $\begin{array}{l}\text { Time } \\
(\min )\end{array}$ & $\begin{array}{c}\text { Group } 1 \\
\text { adults }(\mathrm{M} \pm \text { S.E. })\end{array}$ & $\begin{array}{r}\text { Time } \\
(\mathrm{min})\end{array}$ & $\begin{array}{c}\text { Group } 2 \\
\text { healthy neonates }(\mathrm{M} \pm \text { S.E. })\end{array}$ & $\begin{array}{l}\text { Time } \\
(\min )\end{array}$ & $\begin{array}{c}\text { Group 3 } \\
\text { "Stressed" neonates }(M \pm \text { S.E. })\end{array}$ \\
\hline 0 & $\begin{array}{c}119.7 \pm 24.0 \\
\mathrm{a}\end{array}$ & 0 & $\begin{array}{c}209.1 \pm 40.1 \\
\mathrm{a}\end{array}$ & 0 & $154.1 \pm 23.9$ \\
\hline 40 & $3993.1 \pm 673.7$ & 40 & $\begin{array}{c}5667.9 \pm 1055.8 \\
\mathrm{c}\end{array}$ & 40 & $\begin{array}{c}7670.1 \pm 1077.0 \\
a\end{array}$ \\
\hline 60 & $5154.0 \pm 702.0$ & 60 & $9614.7 \pm 1973.9$ & 60 & $10,522.2 \pm 6634.5$ \\
\hline 80 & $6720.7 \pm 1283.9$ & 80 & $12,955.5 \pm 2199.5$ & 80 & $13,408.4 \pm 1400.7$ \\
\hline
\end{tabular}

$\mathrm{P}$ values refer to comparisons within each group $(1,2,3)$ and relate to successive time intervals (e.g., Group 1,0 vs 40 min., $\left.{ }^{a} P<0.001\right)$.

${ }^{a} P<0.001$

${ }^{b} P<0.01$

' $P<0.05$

${ }^{d} P=N S$.

infants demonstrated significantly greater phagocytosis of type Ic GBS than adult PMNs at $40(P<0.05), 60(P<0.01)$, and 80 $\min (P<0.025)$ (Fig. 2). PMNs from 22 healthy neonates also showed significantly enhanced bacterial uptake at $40(P<0.05)$, $60(P<0.01)$, and $80 \mathrm{~min}(P<0.01)$ when compared to adults (Fig. 3). Radiolabeled GBS uptake did not correlate with birth weight, study age, Apgar scores, or peripheral leukocyte count for the "stressed" infants. Maternal antenatal treatment with dexamethasone did not significantly alter phagocytic capacity in six "stressed" neonates when compared to the remaining "stressed" population.

Radiolabeled bacterial uptake: "stressed" vs healthy neonates. Neutrophils from "stressed" and healthy newborn infants were studied simultaneously on 11 occasions. As noted previously, PMNs from "stressed" and healthy infants demonstrated significantly enhanced phagocytosis at 40,60 , and 80 , min when compared to adults (Fig. 4). There were no significant differences in bacterial uptake between "stressed" and healthy infants at the time points measured.

\section{DISCUSSION}

This study investigated the effect of severe "stress" on neonatal neutrophil phagocytosis, and compared the ability of neonatal and adult PMNs to ingest type Ic group B streptococcus. Neutrophils from both "stressed" and healthy infants demonstrated enhanced bacterial uptake when compared to adults. There were no significant differences in phagocytic capacity between "stressed" and healthy infants. Neutrophils from adults demonstrated a linear increase in bacterial uptake which was maximal by $60 \mathrm{~min}$, whereas PMNs from healthy and "stressed" newborn infants continued to ingest type Ic GBS over the entire 80-min period. Although there are technical limitations of the assay system, which prevent extension of the time intervals for bacterial uptake (e.g., drying of coverslips and loss of PMN monolayer viability), PMN ingestion of type Ic GBS peaks later for the newborn infant than for the adult.

The phagocytic ability of neutrophils from neonates has been investigated and there are conflicting results. In the presence of serum concentrations greater than $10 \%$ (adult donors), the phagocytosis of Staphylococcus aureus, Streptococcus pyogenes, Streptococcus pneumoniae, and Pseudomonas aeruginosa by PMNs from newborn infants was equivalent to that of adults $(6,7,17)$. Miller (21), in contrast, demonstrated that PMNs from newborns were deficient in phagocytosis of yeast particles at lower opsonic serum concentrations. When neutrophils from healthy and sick newborn infants were compared, Forman and Steihm (9) found both phagocytic and killing capacities to be deficient in the infants with abnormal clinical findings.

Shigeoka et al. (29) and Hill et al. (11) assessed neutrophil phagocytosis of type III group B streptococcus using a radiolabeled bacterial uptake technique and chemiluminescence production in response to zymosan or phorbol myristate acetate. PMNs from healthy term infants and neonates with a wide variety of "stress" conditions including prematurity, respiratory distress syndrome,

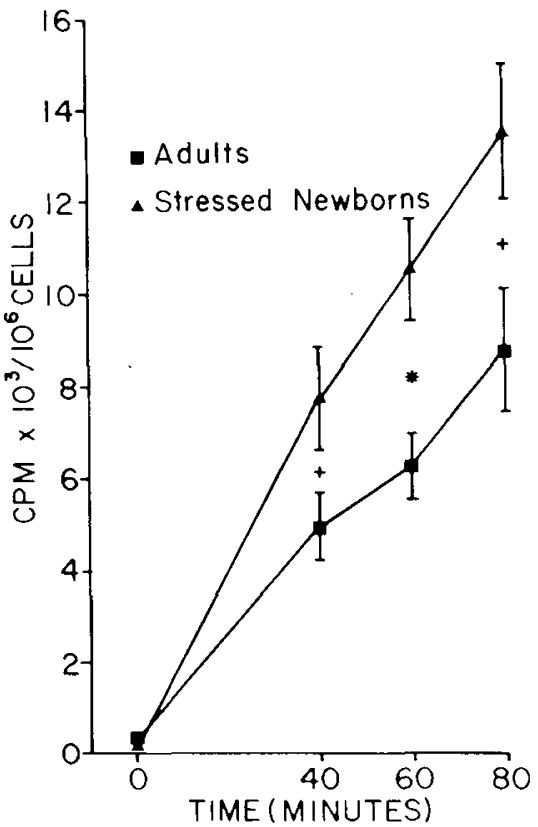

Fig. 2. Radiolabeled bacterial uptake: "Stressed" neonates $(\boldsymbol{\Lambda})$ vs adults (I) (mean \pm S.E.). $P$ values refer to comparisons between groups at a single time. ${ }^{*} P<0.01$ and ${ }^{+} P<0.05$.

sepsis, jaundice, hypoglycemia, and hypocalcemia demonstrated equivalent phagocytosis. Neutrophils from "stressed" infants showed an impaired chemiluminescence response to zymosan and an elevated response to phorbol myristate acetate. These observations suggested that neutrophils from "stressed" neonates demonstrate normal phagocytosis and altered oxidative metabolism (30).

In contrast to previous investigations, in the current study the criteria for stress were either an acute, noninfectious respiratory illness, sepsis, or severe birth asphyxia; 94\% of the "stressed" infants required assisted ventilation. Under these "stress" conditions, the phagocytosis of group B streptococcus was not compromised. PMNs from both healthy and "stressed" newborn infants demonstrated sinificantly greater radiolabeled bacterial uptake when compared to adults using a serum concentration of $5 \%$.

The mechanism responsible for the enhanced phagocytic response of PMNs from neonates is unknown, but may be related to the test organism (type Ic GBS), the concentration (5\%) and opsonin source (high titer adult serum), and PMN adherence. Additional factors which influence phagocytic function include the stage of differentiation of the PMN $(4,27)$, cell metabolism, and PMN membrane dynamics (13). Neutrophils from newborn infants manifest an activated metabolic state, as evidenced by increased nitroblue tetrazolium reduction in comparison to PMNs from adults $(5,12,24)$. It is tempting to speculate that there is a relationship between increased phagocytosis and increased metab- 


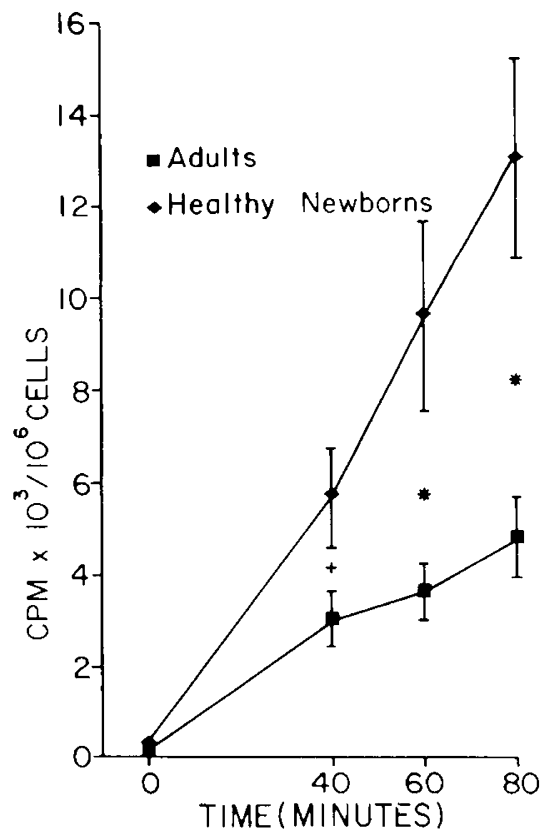

Fig. 3. Radiolabeled bacterial uptake: healthy neonates $(\bullet) v s$ adults (mean \pm S.E.). $P$ values refer to comparisons between groups at a single time. ${ }^{*} P<0.01$ and ${ }^{+} P<0.05$.

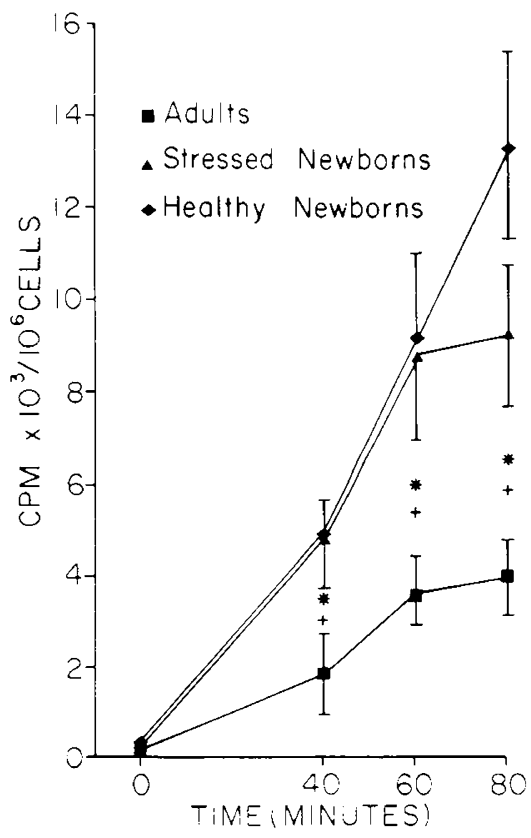

Fig. 4. Radiolabeled bacterial uptake: "stressed" $(\boldsymbol{\Lambda})$ vs healthy $(\bullet)$ neonates $v s$ adults $(\mathbf{})$ (mean \pm (S.E.). * Significant differences between healthy infants and adults (40 $\mathrm{min}, P<0.001 ; 60 \mathrm{~min}, P<0.005$; and 80 min, $P<0.001) .{ }^{+}$Significant differences between "stressed" infants and adults (40 min, $P<0.005$; $60 \mathrm{~min}, P<0.01$; and $80 \mathrm{~min}, P<0.005$ ). $P$ is NS between "stressed" and healthy infants.

olism. In this context, the metabolic regulation is under investigation.

\section{REFERENCES AND NOTES}

1. Allred, C. D., Shigeoka A. O., and Hill H. R.: Evaluation of group B streptococcal opsonins by radiolabelled bacterial uptake. J Immunol. Methods, 26: 5 (1979).

2. Anderson, D. C., Hughes, B. J., and Smith, C. W.: Abnormal mobility of neonatal polymorphonuclear leukocytes. J. Clin. Invest., 68: 863 (1981)

3. Baker, C. J.: Group B streptococcal infections. Adv. Int. Med., 25: 475 (1980).

4. Boner, A., Zeligs, B. J., and Bellanti, J. A.: Chemotactic responses of various differentiational stages of neutrophils from human cord and adult blood. Infect. Immun., 35: 921 (1982).

5. Cocchi, P., Mori, S., and Becattini, A.: Nitroblue-tetrazolium reduction by neutrophils of newborn infants in in vitro phagocytosis test. Acta Pediatr. Scand., 60: 475 (1971).

6. Coen, R., Grush, O., and Kauder, E.: Studies of bactericidal activity and metabolism of the leukocyte in full-term neonates. J. Pediatr., 75: 400 (1969).

7. Dossett, J. H., Williams, R. C., and Quie, P. G.: Studies on interaction of bacteria, serum factors and polymorphonuclear leukocytes in mothers and newborns. Pediatrics, 44: 49 (1969).

8. Fontan, G., Lorente, F., Rodriguez, G., and Ojeda, J. A.: Granulocyte adherence in umbilical cord blood. J. Pediatr., 94: 969 (1979).

9. Forman, M. L. and Stiehm, E. R.: Impaired opsonic activity but normal phagocytosis in low-birth-weight infants. N. Engl. J. Med., 281: 926 (1969).

10. Franciosi, R. A., Knostman, J. D., and Zimmerman, R. A.: Group B streptococcal neonatal and infant infections. J. Pediatr., 82: 707 (1973)

11. Hill, H. R., Shigeoka, A. O., Hall, R. T., and Hemming, V. G.: Neonatal cellular and humoral immunity to group B streptococci. Pediatr. Supp., 64: 787 (1979),

12. Humbert, J. R., Kurtz, M. L., and Hathaway, W. E.: Increased reduction of nitroblue-tetrazolium by neutrophils of newborn infants. Pediatrics, 45: 125 (1970)

13. Klebanoff, S. J. and Clark, R. A.: Phagocytosis. In, The Neutrophil: Function and Clinical Disorders. North Holland Publishing Co., New York, 1978, pp. 163216.

14. Krause, P. J., Maderazo, E. G., and Scroggs, M.: Abnormalities of neutrophil adherence in newborns. Pediatrics, 69: 184 (1982).

15. Laurenti, F., Ferro, R., Marzetti, G., Rossini, M., and Bucci, G.: Neutrophil chemotaxis in preterm infants with infections. J. Pediatr., 96: 468 (1980).

16. Mandell, G. L.: Effect of temperature on phagocytosis by human polymorphonuclear neutrophils. Infect. Immun., 12: 221 (1975).

17. McCracken, G. H. and Eichenwald, H. F.: Leukocyte function and the development of opsonic and complement activity in the neonate. Am. J. Dis. Child., 121: 120 (1971)

18. Mease, A. D., Burgess, D. P., and Thomas, P. J.: Irreversible neutrophil aggregation: A mechanism of decreased newborn neutrophil chemotactic response. Am. J. Pathol., 104: 98 (1981)

19. Miller, M. E.: Phagocytic Cells. In, Host Defenses in the Human Neonate. T. K. Oliver, Ed., Grune \& Stratton, New York, 1978, pp. 59-71.

20. Miller, M. E.: Chemotactic function in the human neonate: Humoral and cellular aspects. Pediatr. Res., 5: 487 (1971).

21. Miller, M. E.: Phagocytosis in the newborn infant: Humoral and cellular factors. J. Pediatr., 74: 255 (1969)

22. Miller, M. E.: Developmental maturation of human neutrophil motility and its relationship to membrane deformability. In, The Phagocytic Cell in Host Resistance. J. A. Bellanti, and D. H. Dayton, Eds., Raven Press, New York, 1975.

23. Mills, E. L., Thompson, T., Bjorksten, B., Filipovich, D. and Quie, P. G.: The chemiluminescence response and bactericidal activity of neutrophils from newborns and their mothers. Pediatrics, 63: 429 (1979).

24. Park, B. H., Holmes, B. and Good, R. A.: Metabolic activities in leukocytes of newborn infants. J. Pediatr., 76: 237 (1970).

25. Polin, R. A., Douglas, S. D., Kasper, D. L., and Baker, C. J.: Enzyme-linked immunosorbent assay for measurement of antibody to type III, group B streptococci. J. Clin. Micro., 15(6): 991 (1982).

26. Quie, P. G. and Mills, E. L.: Bactericidal and metabolic function of polymorphonuclear leukocytes. Pediatr. Suppl., 64: 719 (1979).

27. Rabellino, E. M., Ross, G. D., Trang, H. T., Williams, N., and Metcalf, D Membrane receptors of mouse leukocytes. Sequential expression of membrane receptors and phagocytic capacity during leukocyte differentiation. J. Exp. Med., 147: 434 (1978)

28. Repo, H., Jokipii, A. M., Leirisalo, M., and Kosunen, T. U.: Leukocyte motility in the newborn: Determination of spontaneous movement is essential in the in vitro assessment of neutrophil chemotaxis. Clin. Exp. Immunol., 40: 620 (1980).

29. Shigeoka, A. O., Santos, J. I., and Hill, H. R.: Functional analysis of neutrophil granulocytes from healthy, infected, and stressed neonates. J. Pediatr., 95: 454 (1979).

30. Shigeoka, A. O., Charette, R. P., Wyman, M. L., and Hill, H. R.: Defective oxidative metabolic responses of neutrophils from stressed neonates. J. Pediatr., 98: 392 (1981).

31. Tono-Oka, T., Nakayama, M., Uehara, H., and Matsumoto, S.: Characteristics of impaired chemotactic function in cord blood leukocytes. Pediatr. Res., 13: 148 (1979).

32. Van Epps, D. E., Goodwin, J. S., and Murphy, S.: Age-dependent variations in polymorphonuclear leukocyte chemiluminescence. Infect. Immun., 22: 57 (1978).

33. Wright, W. C., Ank, B. J., Herbert, J., and Stiehm, E. R.: Decreased bactericidal activity of leukocytes of stressed newborn infants. Pediatrics, 56: 579 (1975).

34. The authors thank Barbara Erwins for editorial assistance.

35. Requests for reprints should be addressed to: Dr. Mary Catherine Harris, Division of Neonatology, The Children's Hospital of Philadelphia, 34th Street \& Civic Center Boulevard, Philadelphia, PA, 19104

36. This research was supported by the Thrasher Research Fund, The Kroc Foundation and the National Institutes of Health, Department of Human Services Grants 1 RO1 HL 27068 and 1 POI NS 17752.

37. Received for publication April 14, 1982.

38. Accepted for publication August 26, 1982. 